\title{
Soybean morphophysiology and yield response to seeding systems and plant populations
}

\author{
Raniele Souza ${ }^{1}$, Itamar Teixeira ${ }^{1 *}$, Elton Reis ${ }^{1}$, and Alessandro Silva ${ }^{2}$
}

\section{ABSTRACT}

Soybean (Glicine max [L.] Merr.) is recognized worldwide for its economic importance; it has the ability to adapt to environmental and management changes, particularly when using different spacing and plant populations. This study aimed to investigate the influence of morphological changes of the crisscross seeding system on grain growth and yield. Work was conducted at the Experimental Station of Anapolis, Goiás, Brazil, of the Technical Assistance Agency, Rural Extension and Agricultural Research of Goiás (EMATER) for the 2013-2014 harvest. The experimental design was a randomized block and $2 \times 3 \times$ 3 factorial, with four replicates. Treatments consisted of two seeding systems (conventional-in line and crossedcrisscross), three soybean cultivars with different growth habits ('BRS Valiosa RR' determined, 'NA 7337 RR' semi-determined, and 'BMX Potência RR' indeterminate) and three sowing densities $(245000,350000$, and 455000 plants $\left.\mathrm{ha}^{-1}\right)$. Results showed that at $50 \mathrm{~d}$ after emergence the cross-seeding system showed higher closing among lines promoted by the increase in population. Leaf area and the leaf area index were not affected by the seeding system. Leaf area was lower with increasing plant density with no significant difference in relation to the leaf area index. The cross-system enabled a potential yield of $4504 \mathrm{~kg} \mathrm{ha}^{-1}$ corresponding to an approximate $8 \%$ increase compared with conventional sowing using equidistant lines with 0.5 $\mathrm{m}$ spacing.

Key words: Glycine max, spatial arrangement, growth habit, yield.

${ }^{1}$ Universidade Estadual de Goiás (UEG), Departamento de Engenharia Agrícola, Campus Henrique Santillo, CEP: 75132-400, Anápolis, Goiás, Brasil. "Corresponding author (itamar.texeira@ueg.br).

${ }^{2}$ Universidade de Rio Verde (Unirv), Departamento de Agronomia, CEP: 75901-970, Rio Verde, Goiás, Brasil.

Received: 9 April 2015.

Accepted: 14 September 2015.

doi:10.4067/S0718-58392016000100001

\section{INTRODUCTION}

Studies on spatial distribution adequacy in soybean in a cultivation area have been of interest in recent years motivated by the increase of grain yield per agricultural unit. This is justified by the ability of soybean (Glicine max [L.] Merr.) plants to adapt to various types of cultivation, a characteristic known as phenotypic plasticity (Heiffig et al., 2006; Akond et al., 2013; Balbinot Junior et al., 2015). Besides the need to find suitable soil and climate conditions, crop competition should be minimized; plant arrangements studies provide information on minimizing intraspecies competition and maximizing the use of environmental resources (Walker et al., 2010; Bellaloui et al., 2015).

In soybean, numbers of branches and leaves per plant are characteristics that change in each cultivar, but plants appear quite sensitive when considering changes in population density (De Bruin and Pedersen, 2008; Board and Kahlon, 2013; Suhre et al., 2014). This behavior is due to a framework of these three growth habit groups: determinate, indeterminate, and semideterminate (Tian et al., 2010; Soares et al., 2015). Knowledge of these characteristics influences population distribution of the crop in the field, so the best space arrangement should enable high agricultural productivity (Board and Kahlon, 2013).

Cross-seeding is a new cultivation system that is being increasingly used, especially in Midwestern Brazil. It is characterized by crossing sowing lines and forming a line grid on the cultivation area. Recent studies conducted with soybean in Midwestern and Southern Brazil have shown contradictory results regarding this system, such as the study by Lima et al. (2012), whose results indicate that sowing in crossed lines under no-tillage was more productive than with noncrossed lines with an $8.6 \%$ increase with 'M7211RR' (indeterminate habit). The lack of effect of cross planting on soybean yield with indeterminate ('BRS 359 RR') and determinate ('BRS 294 RR' and 'BRS 295 RR') growth habits was verified by Procópio et al. (2013) and Balbinot Junior et al. (2015), respectively.

The aim of this study was to evaluate the influence of crossseeding and conventional sowing on yield components of soybean cultivars with different growth habits and different population densities.

\section{MATERIALS AND METHODS}

The experiment was conducted during the harvest of the 20132014 season in the experimental area belonging to Emater-GO, 


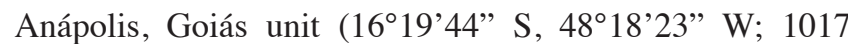
$\mathrm{m}$ a.s.1.) The climate is tropical wet, Aw, according to the Köppen classification; it is characterized by dry winters and rainy summers. The experiment was established on 11 December 2013 and the prevailing weather conditions throughout the crop cycle are shown in Figure 1.

The soil of the area is classified as dystrophic Red Latosol; samples were collected at the $0-20 \mathrm{~cm}$ layer. Results of chemical analyses were $\mathrm{pH} 5.5,4.3 \mathrm{mg} \mathrm{P} \mathrm{dm}^{-3}$, $36 \mathrm{mg} \mathrm{K} \mathrm{dm}{ }^{-3}, 2.7 \mathrm{cmol}_{\mathrm{c}} \mathrm{Ca} \mathrm{dm}^{-3}, 0.8 \mathrm{cmol}_{\mathrm{c}} \mathrm{Mg} \mathrm{dm}^{-3}, 0.0$ $\mathrm{cmol}_{\mathrm{c}} \mathrm{Al} \mathrm{dm}{ }^{-3}, 0.19 \mathrm{mg} \mathrm{B} \mathrm{dm}^{-3}, 4.0 \mathrm{mg} \mathrm{Cu} \mathrm{dm}^{-3}, 42.1 \mathrm{mg}$ Fe $\mathrm{dm}^{-3}, 10.3 \mathrm{mg} \mathrm{Mn} \mathrm{dm}^{-3}, 3.0 \mathrm{mg} \mathrm{Zn} \mathrm{dm}^{-3}$, base saturation $57.21 \%$, organic matter: $31 \mathrm{~g} \mathrm{dm}^{-3}, 30 \%$ clay, $62 \%$ sand, and $0.8 \%$ silt texture.

\section{Experimental design and treatments}

A completely randomized design, $2 \times 3 \times 3$ factorial with four replicates was used. Treatments consisted of two seeding systems (conventional line and crossed criss-cross), three soybean cultivars with different growth habits and different types of growth (determinate 'BRS Valiosa RR', semi-determinate 'NA 7337 RR', and indeterminate 'BMX Potência RR'), and three sowing densities $(245000,350000$, and 455000 plants ha ${ }^{-1}$ ).

Plots consisted of five 5-m long rows with $0.45 \mathrm{~m}$ spacing. The usable area consisted of three central lines and $1 \mathrm{~m}$ was disregarded at each end.

\section{Cultural practices}

The soil was conventionally prepared with a moldboard plow and a light-screening system with overall disking harrow to incorporate crop residues of maize previously grown in the area. The area was manually plowed at a depth of approximately $0.10 \mathrm{~m}$, and basic fertilization was later done according to the recommendation for soybean cultivation to obtain $3000 \mathrm{~kg} \mathrm{ha}^{-1}$ productivity. The amount of $400 \mathrm{~kg} \mathrm{ha}^{-1}$ of NPK 04-30-16 formula was applied. Seeds were first treated with the fungicide carbendazim $(15 \%)+$ thiram (35\%) at a rate of $200 \mathrm{~mL}$ per $100 \mathrm{~kg}$ seed, and they were then inoculated with Bradyrhizobium elkanii (SEMIA 587) and Bradyrhizobium japonicum bacteria (SEMIA 5079) with a bacterial concentration of $5.0 \times 10^{9} \mathrm{CFU} \mathrm{mL}^{-1}$ at a rate of $150 \mathrm{~mL}$ of the commercial product for $50 \mathrm{~kg}$ seed. Seed distribution was performed manually in the furrow with a polyester tape appropriately marked to define the distance between seeds. Later $24 \mathrm{~kg} \mathrm{~K}_{2} \mathrm{O} \mathrm{ha}^{-1}$ was applied $30 \mathrm{~d}$ after sowing (DAS). Its source was potassium chloride.

Weeds were controlled by applying glyphosate 25 DAS with the recommended rate of $3 \mathrm{~L} \mathrm{ha}^{-1}$, and fomesafen $(12.5 \%)+$ fluazifop-p-butyl (12.5\%) 33 DAS to control spiderwort (Commelina benghalensis L.) and "corda de viola" (Ipomoea sp.) at the recommended rate of $2 \mathrm{~L} \mathrm{ha}^{-1}$. Six applications of deltamethrin $(2.5 \%)$ were carried out at a rate of $300 \mathrm{~mL} \mathrm{ha}^{-1}$ to control velvet bean caterpillar (Anticarsia gemmatalis Hübner, 1818), looper caterpillar (Pseudoplusia includens), Nezara viridula L., and little stink bug (Piezodorus guildinii Westwood, 1837), all of which often occurred during the experiment. As a preventive measure, three applications of fungicide with trifloxystrobin $(10 \%)+$ tebuconazole $(20 \%)$ at a rate of $500 \mathrm{~mL} \mathrm{ha}^{-1}$ in the short cycle 'NA7337 RR' and 'BMX Potência RR', four applications in the late growing cycle 'BRS Valiosa RR', were made to control powdery mildew (Erysiphe diffusa), Asian rust (Phakopsora pachyrhizi Syd. \& P. Syd. 1914), blight-leaf (Cercospora kikuchii [Tak. Matsumoto \& Tomoy.] M.W. Gardner 1927), septoria (Septoria glycines Hemmi 1915), anthracnose (Colletotrichum truncatum [Schwein.] Andrus \& W.D. Moore 1935), and target spot (Corynespora cassiicola [Berk. \& M.A. Curtis] C.T. Wei 1950). Other standard farming practices were used with the crops.

Figure 1. Rainfall distribution and average daily air temperature during the field experiment. Anápolis, Goiás, $2013-2014$.

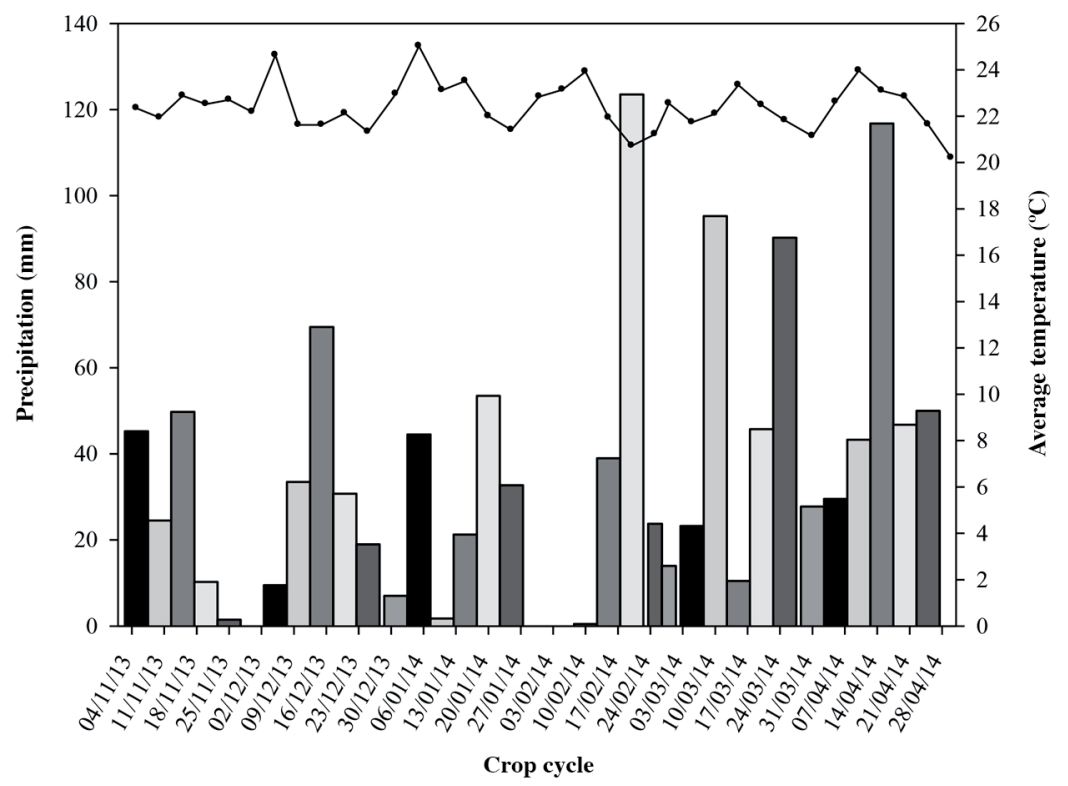




\section{Measurements}

Tracking was done of the major soybean plant growth stages for each cultivar by observing the soybean phenological scale developed by Fehr and Caviness (1977). The ground cover rate between lines was evaluated in days until reaching maximum ground cover between the lines by soybean plant foliage. It was measured with a graduated ruler every $5 \mathrm{~d}$ after 30 DAS.

Leaf area (LA) was determined at the $\mathrm{R}_{1}$ stage for 'BRS Valiosa RR' and at the $\mathrm{R}_{2}$ stage for the others. Ten plants were randomly collected on the fourth line of each plot in the lines parallel to the usable area. In the laboratory, leaves of each plant were individually detached and distributed over a white surface and immediately photographed using a digital camera (Cyber-Shot, Sony, Tokyo, Japan) with a 12.1 megapixel resolution. The reading was taken through the image analysis software ImageJ (NIMH, 2015). The leaf area index (LAI) was determined by the relationship between the sum of the area of the leaves of a plant and the soil surface it occupies as in the following expression:

$$
\mathrm{LAI}=(\mathrm{LA} \times \mathrm{FS}) / 1000
$$

where LA is mean leaf area of evaluated soybean plants $\left(\mathrm{m}^{2}\right)$ and FS is the final stand of plants ha ${ }^{-1}$.

During harvest (growth stages $\mathrm{R}_{8}$ and $\mathrm{R}_{9}$ ), agronomic characters were assessed with 10 plants harvested in the usable area of each plot by direct counting; plant height (distance between the neck of the plant and the apical end of the main shaft) was measured with a graduated ruler and the mean height of the 10 plants was obtained. The number of branches inserted into the main stem of each of the 10 plants was counted and the mean number of branches per plant was obtained. The number of pods per plant was calculated by directly counting the total number of pods formed on each of the 10 plants and the final mean was obtained. When pods of the 10 plants in the usable area were counted, grains related to the total number of pods were also counted. Thus, the mean number of seeds per pod was obtained. Eight sub-samples of 100 seeds per plot were counted to determine mean weight using an analytical balance with a sensitivity of $0.001 \mathrm{~g}$. Grain yield was determined in $\mathrm{kg} \mathrm{ha}^{-1}$ by threshing all the plants in the plot. Seed mass water content was adjusted to $13 \%$.

\section{Statistical analysis}

Data were subjected to ANOVA; when relevant, and the Scott-Knott test at $5 \%$ probability was used to discriminate possible differences among treatments. The SISVAR 5.3 software was used for statistical analysis (Ferreira, 2011).

\section{RESULTS AND DISCUSSION}

All treatments had $100 \%$ closed crop interline canopy at 55 DAS (Table 1). At 30 and 35 DAS, the conventional sowing system had faster closure. However, the cross-seeding system accentuated closure; it was faster and higher after 45 DAS
Table 1. Mean values of the canopy closure rate for different cropping systems, growth habits, and soybean sowing densities.

\begin{tabular}{lcccccc}
\hline Treatments & \multicolumn{5}{c}{ Closure rate } \\
\hline Seeding systems & $\mathrm{T} 1$ & $\mathrm{~T} 2$ & $\mathrm{~T} 3$ & $\mathrm{~T} 4$ & $\mathrm{~T} 5$ & $\mathrm{~T} 6$ \\
Conventional & $47.6 \mathrm{a}$ & $55.4 \mathrm{a}$ & $58.5 \mathrm{a}$ & $60.4 \mathrm{a}$ & $71.2 \mathrm{~b}$ & $90.0 \mathrm{a}$ \\
Crossed & $44.2 \mathrm{~b}$ & $52.4 \mathrm{~b}$ & $57.18 \mathrm{a}$ & $62.7 \mathrm{a}$ & $78.0 \mathrm{a}$ & $90.0 \mathrm{a}$ \\
Types of growth & & & & & & \\
Determinate & $44.5 \mathrm{~b}$ & $53.4 \mathrm{a}$ & $58.1 \mathrm{a}$ & $65.6 \mathrm{a}$ & $77.0 \mathrm{a}$ & $90.0 \mathrm{a}$ \\
Semi-determinate & $48.4 \mathrm{a}$ & $54.4 \mathrm{a}$ & $58.9 \mathrm{a}$ & $62.5 \mathrm{a}$ & $76.1 \mathrm{a}$ & $90.0 \mathrm{a}$ \\
Indeterminate & $44.9 \mathrm{~b}$ & $53.2 \mathrm{a}$ & $56.5 \mathrm{~b}$ & $56.5 \mathrm{~b}$ & $70.6 \mathrm{~b}$ & $90.0 \mathrm{a}$ \\
Sowing densities, plants ha- & & & & & \\
245 000 & $43.7 \mathrm{~b}$ & $52.6 \mathrm{~b}$ & $55.2 \mathrm{c}$ & $58.7 \mathrm{a}$ & $71.6 \mathrm{~b}$ & $90.0 \mathrm{a}$ \\
350000 & $45.6 \mathrm{~b}$ & $53.6 \mathrm{~b}$ & $58.1 \mathrm{~b}$ & $62.7 \mathrm{a}$ & $75.5 \mathrm{a}$ & $90.0 \mathrm{a}$ \\
455000 & $48.4 \mathrm{a}$ & $55.4 \mathrm{a}$ & $60.3 \mathrm{a}$ & $63.2 \mathrm{a}$ & $76.7 \mathrm{a}$ & $90.0 \mathrm{a}$ \\
Mean & 45.9 & 53.9 & 57.8 & 61.5 & 74.6 & 90.0 \\
\hline
\end{tabular}

Means followed by the same letter in a column did not significantly differ according to the Scott Knott test at 5\% probability. Crop closure rates: T1: $30 \mathrm{~d}$ after sowing (DAS); T2: 35 DAS; T3: 40 DAS; T4: 45 DAS; T5: 50 DAS.

than at 50 DAS with $9.56 \%$ more closure. The LAI of the cross-seeding system was $7 \%$ higher than in the line system, which could explain better closure in the cross-system.

The faster closure in cross-lines was also observed by Lima et al. (2012), who pointed out that the crop reaches the maximum growth phase earlier under this condition. Reducing spacing and using more equidistant spacing allows an increase in light utilization at the beginning of crop development, which is caused by higher LAI and biomass production and higher productivity as a consequence (Cox and Cherney, 2011).

At 35 DAS, cultivars with semi-determinate and indeterminate growth did not differ significantly and exhibited faster closure. The increase in sowing density influenced the closure rate during the evaluation period. As the seeding rate increases, interline closure increases.

Neither LA nor LAI were influenced by the seeding systems (Table 2), demonstrating that spatial distribution in this situation did not cause morphological changes in plant architecture. These results are relevant for shade issues, leaf senescence in the lower third, and flower and pod fixation (Board and Kahlon, 2011); they are also positive for phytosanitary control (Kumudini et al., 2008) and weed management (Arce et al., 2009).

Table 2. Mean values of leaf area (LA) and leaf area index (LAI) for different cropping systems, growth habits, and soybean seeding rate.

\begin{tabular}{lcc}
\hline Treatments & LA $\left(\mathrm{m}^{2}\right)$ & LAI \\
\hline Seeding systems & - & - \\
Conventional & $0.24 \mathrm{a}$ & $7.09 \mathrm{a}$ \\
Crossed & $0.25 \mathrm{a}$ & $7.56 \mathrm{a}$ \\
Types of growth & & \\
Determinate & $0.28 \mathrm{a}$ & $8.40 \mathrm{a}$ \\
Semi-determinate & $0.22 \mathrm{~b}$ & $6.49 \mathrm{~b}$ \\
Indeterminate & $0.23 \mathrm{~b}$ & $7.08 \mathrm{~b}$ \\
Sowing densities, plants ha ${ }^{-1}$ & & $7.61 \mathrm{a}$ \\
245000 & $0.32 \mathrm{a}$ & $7.74 \mathrm{a}$ \\
350000 & $0.24 \mathrm{~b}$ & $6.62 \mathrm{a}$ \\
455000 & $0.17 \mathrm{c}$ & 7.32 \\
Mean & 0.24 & \\
\hline
\end{tabular}

Means followed by the same letter in a column did not significantly differ according to Scott Knott test at 5\% probability. 
The cultivar with a determinate growth habit had higher LA (19.83\%) and LAI (15.7\%) values compared with the indeterminate growth habit and semi-determinate cultivars due to the higher number of lateral branches observed in the determinate growth cultivar (Table 2). The LAI did not differ across different population levels because this index is compensated between LA and number of plants per area, which is attributed to the high capacity of soybean morphological adaptation. These results differ from those obtained by Heiffig et al. (2006).

The cultivation system did not affect plant height because intraspecific competition did not increase in the line (Table 3 ) and there were no significant differences in LA and LAI among systems. On the other hand, the cultivar with a determinate height was $16 \mathrm{~cm}$ higher than the other cultivars This may be explained by higher competition among individuals as observed in higher LA, LAI, and number of branches. In response to increased sowing density, there was a $3.3 \mathrm{~cm}$ increase in height from the smallest to the largest population (Table 3); this confirms results found by De Bruin and Pedersen (2008), who observed a $6 \mathrm{~cm}$ increase in the final population from 258600 to 402700 plants.

The number of branches was $7 \%$ higher in the line planting system, but the difference was nonsignificant. This result is confirmed because there were nonsignificant differences in the results for LA, LAI, and plant height.

The number of branches per plant was higher in determinate growth habit cultivars and lower in indeterminate and semi-determinate growth habit cultivars (Table 3). These results can be explained by higher LA and LAI obtained by determinate growth cultivars and the highest number of branches, which supports other research results (Robinson and Wilcox, 1998; Kilgore-Norquest and Sneller, 2000).

The increased competition between plants within the line resulted in a change in the number of branches per plant. The increase in seeding rate decreases the emission of the number of branches, unlike the density of 245000 plants ha ${ }^{-1}$, which had the highest number of branches (Table 3). Cox

Table 3. Mean values for plant height $(\mathrm{PH})$, number of branches per plant (NBP), number of pods per plant (NPP), 1000-seed weight (TSW), and grain yield (YIELD) as related to the seeding system, growth habit, and soybean seeding rate.

\begin{tabular}{lccccc} 
& \multicolumn{5}{c}{ Agronomic characteristics } \\
\cline { 2 - 6 } Treatments & $\mathrm{PH}$ & NBP & NPP & TSW & Yield \\
\hline & $\mathrm{cm}$ & & & $\mathrm{g}$ & $\mathrm{kg} \mathrm{ha}^{-1}$ \\
Seeding systems & & & & & \\
Conventional & $92.82 \mathrm{a}$ & $5.05 \mathrm{a}$ & $58.88 \mathrm{a}$ & $149.85 \mathrm{a}$ & $4186.47 \mathrm{~b}$ \\
Crossed & $93.77 \mathrm{a}$ & $4.73 \mathrm{a}$ & $59.69 \mathrm{a}$ & $151.64 \mathrm{a}$ & $4509.02 \mathrm{a}$ \\
Determinate & $104.86 \mathrm{a}$ & $7.37 \mathrm{a}$ & $64.85 \mathrm{a}$ & $159.30 \mathrm{a}$ & $4111.76 \mathrm{~b}$ \\
Semi-determinate & $88.71 \mathrm{~b}$ & $3.74 \mathrm{~b}$ & $65.66 \mathrm{a}$ & $150.67 \mathrm{~b}$ & $4529.54 \mathrm{a}$ \\
Indeterminate & $86.30 \mathrm{c}$ & $3.57 \mathrm{~b}$ & $47.34 \mathrm{~b}$ & $147.04 \mathrm{~b}$ & $4411.95 \mathrm{a}$ \\
Sowing densities, plants ha-1 & & & & \\
245 000 & $91.58 \mathrm{c}$ & $5.75 \mathrm{a}$ & $73.62 \mathrm{a}$ & $149.67 \mathrm{a}$ & $4422.32 \mathrm{a}$ \\
350000 & $93.40 \mathrm{~b}$ & $4.75 \mathrm{~b}$ & $57.59 \mathrm{~b}$ & $150.69 \mathrm{a}$ & $4434.12 \mathrm{a}$ \\
455000 & $94.90 \mathrm{a}$ & $4.18 \mathrm{~b}$ & $46.65 \mathrm{c}$ & $151.87 \mathrm{a}$ & $4186.81 \mathrm{a}$ \\
Mean & 93.29 & 4.89 & 59.28 & 151.34 & 4348.99 \\
\hline
\end{tabular}

Means followed by the same lower-case letter in a column did not significantly differ according to the Scott Knott test at 5\% significance. and Cherney (2011) also obtained a $20 \%$ reduction in the number of branches per plant by increasing sowing density from 321000 to 421000 plants ha $^{-1}$. In a soybean crop study on different sowing densities and different row spacing, Procópio et al. (2013) found that competition in the line more significantly affects the number of branches than spacing between lines. In their study, the change from 375000 seeds to 562500 seeds was more harmful than changing spacing from 0.40 to $0.60 \mathrm{~m}$. For Procópio et al. (2013) and Balbinot Junior et al. (2015), using higher densities promotes greater competition among plants due to lower emissions of lateral branches, thus reducing productivity per plant. In addition, higher plant density in the line provides more competition for natural resources essential for vegetative growth and lesser grain formation.

Regarding the number of pods, nonsignificant differences were found between seeding systems (Table 3). However, in relation to the growth habit, the indeterminate growth cultivar showed a lower number of pods per plant in response to fewer branches, $107 \%$ less than the determinate growth cultivar. For several issues, Specht et al. (1999) state that the differences between cultivars are explained by genetic constitution and environmental influence. Branches are more important for indirect selection of productive cultivars.

In response to fewer side branches, the number of pods per plant was reduced as sowing density increased. Sowing density of 245000 plants showed a higher number of pods than the 350000 and 455000 plant densities, which decreased by $22 \%$ and $37 \%$, respectively. The same relationship was observed in a study conducted by Heiffig et al. (2006) when separately analyzing $0.20 \mathrm{~m}$ spacing between lines; the number of pods per plant decreased from 106 to 29 when seeding density was altered from 70000 to 350000 plants. However, the reduced number of pods was more significant (72.9\%) when spacing was reduced.

Thousand-grain weight was nonsignificantly influenced by either the seeding system or density, but only by cultivar (Table 3). The determinate growth cultivar showed the best result for 1000-grain weight (159.3 g); it was superior to semideterminate $(5.7 \%)$ and indeterminate $(8.33 \%)$ cultivars, respectively, that is, 150.675 and $147.04 \mathrm{~g}$, which did not differ significantly. Lima et al. (2012), in a cross-seeding study, also found nonsignificant differences in 100-grain weight in two cultivars, 'TMG Anta82 RR' with semideterminate growth and 'M 7211 RR' with indeterminate growth. However, results in the literature about the effects of plant population on 1000-grain weight vary; Cox and Cherney (2011) found nonsignificant differences in changing spacing and plant density. Suhre et al. (2014) showed that plant density in the line increases linearly with seed mass, but the difference was higher in newer cultivars. Characteristics, such as number of seeds per pod and 1000-seed weight, are mostly influenced by genetic factors.

Productivity results enabled us to observe that the crossseeding system allowed obtaining higher grain yield, 4509 $\mathrm{kg} \mathrm{ha}^{-1}$, while the conventional system showed a value of $4186 \mathrm{~kg} \mathrm{ha}^{-1}$, that is, a positive difference of $322.55 \mathrm{~kg} \mathrm{ha}^{-1}$ 
or $7.7 \%$ (Table 3). Results are close to those found by Lima et al. (2012) also under Cerrado conditions, whereas the cross-seeding system showed a productive increase of $8.6 \%$ or $287 \mathrm{~kg} \mathrm{ha}^{-1}$ compared with conventional planting. Mean yield in cross-seeding, $4509 \mathrm{~kg} \mathrm{ha}^{-1}$, was $53 \%$ higher than the national productivity for the 2012-2013 crop and 50\% higher than mean productivity of the Midwest, $3012 \mathrm{~kg} \mathrm{ha}^{-1}$ (Conab, 2014). Therefore, regardless of the extrapolation of results obtained in experimental areas, the reflection on the potential of the cross-seeding technique on yield from genetic materials currently used on a large scale by farmers is evident; moreover, regardless of the growth habit and population densities used, intensified technological actions that allow achieving higher yields are made possible.

The change in seeding density did nonsignificantly influence yield, which is consistent with results obtained by De Bruin and Pedersen (2008), who verified that changes in the final population did not cause changes in final soybean production. Other studies have also found that there was no increase in soybean grain yield with higher seeding density (Lee et al., 2008). The fact that soybean has the capacity to compensate space in the canopy and maintain yield can be seen as the probable hypothesis to explain this behavior (Heiffig et al., 2006; Akond et al., 2013; Balbinot Junior et al., 2015).

\section{CONCLUSIONS}

There was a better distribution of plants over the cultivation area in the cross-seeding system because of the rapid closure between lines even with nonsignificant differences between the systems in relation to leaf area, leaf area index, plant height, and number of branches per plant. The cross-seeding system allowed increasing grain yield in semi-determinate and indeterminate growth cultivars. Increased planting density and growth habit did not promote an increase in soybean yield.

\section{ACKNOWLEDGEMENTS}

The authors acknowledge the support of Coordenação de Aperfeiçoamento de Pessoal de Nível Superior (CAPES) and Conselho Nacional de Desenvolvimento Científico e Tecnológico (CNPq) for the Research Productivity scholarship granted to the second and fourth authors.

\section{REFERENCES}

Akond, M., R. Bobby, R. Bazzelle, W. Clark, S.K. Kantartzi, K Meksem, et al. 2013. Effect to two row spaces on several agronomic traits in soybean [Glycine max (L.) Merr.] Atlas Journal of Plant Biology 1:18-23. doi:10.5147/ajpb.2013.0073.

Arce, G.D., P. Pedersen, and R.G. Hartzler. 2009. Soybean seeding rate effects on weed management. Weed Technology 23:17-22. doi:10.1614/WT-08-060.1.
Balbinot Junior, A.A., S.O. Procópio, H. Debiasi, J.C. Franchini, e F. Panison. 2015. Semeadura cruzada em cultivares de soja com tipo de crescimento determinado. Semina: Ciências Agrárias 36:1215-1226. doi:10.5433/1679-0359.2015v36n3p1215.

Bellaloui, N., H.A. Bruns, H.K. Abbas, A. Mengistu, D.K. Fisher, and K.N. Reddy. 2015. Effects of row-type, row-spacing, seeding rate, soil-type, and cultivar differences on soybean seed nutrition under us Mississippi Delta conditions. PLoS ONE 10:1-23. doi:10.1371/journal.pone.0129913.

Board, J.E., and C.S. Kahlon. 2011. Soybean yield formation: what controls it and how it can be improved. p. 1-36. In El-Shemy, H. (ed.) Soybean physiology and biochemistry. InTech Open Access, Rijeka, Croatia. doi:10.5772/20073.

Board, J.E., and C.S. Kahlon. 2013. Morphological responses to low plant population differ between soybean genotypes. Crop Science 53:1109-1119. doi:10.2135/cropsci2012.04.0255.

Conab. 2014. Acompanhamento da safra Brasileira: grãos. Companhia Nacional de Abastecimento (Conab), Brasília, DF, Brazil. Available at http://www.conab.gov.br/OlalaCMS/ uploads/arquivos/14_12_10_08_51_33_boletim_graos_ dezembro_2014.pdf (accessed March 2014).

Cox, W.J., and J.H. Cherney. 2011. Growth and yield responses of soybean to row spacing and seeding rate. Agronomy Journal 103:123-128. doi:10.2134/agronj2010.0316.

De Bruin, J.L., and P. Pedersen. 2008. Effect of row spacing and seeding rate on soybean yield. Agronomy Journal 100:704710. doi:10.2134/agronj2007.0106.

Fehr, W.R., and C.E. Caviness. 1977. Stages of soybean development. Cooperative Extension Service, Agriculture and Home Economics Experiment Station, Iowa State University, Ames, Iowa, USA.

Ferreira, D.F. 2011. Sisvar: a computer statistical analysis system. Ciência e Agrotecnologia 35:1039-1042. http://dx.doi. org/10.1590/S1413-70542011000600001.

Heiffig,L.S., G.M.S. Câmara, L.A. Marques, D.B.Pedroso, e S.M.S Piedade. 2006. Fechamento e índice de área foliar da cultura da soja em diferentes arranjos espaciais. Bragantia 65:285-295. http://dx.doi.org/10.1590/S0006-87052006000200010.

Kilgore-Norquest, L., and C.H. Sneller. 2000. Effect of stem termination on soybean traits in southern U.S production systems. Crop Science 40:83-90. doi:10.1016/j. agrformet.2003.09.002.

Kumudini, S., C.V. Godoy, J.E. Board, J. Omielan, and M. Tollenaar. 2008. Mechanisms involved in soybean rust-induced yield reduction. Crop Science 48:2334-2342. doi:10.2135/ cropsci2008.01.0009.

Lee, C.D., D.B. Egli, and D.M. TeKrony. 2008. Soybean response to plant population at early and late planting dates in the Mid-South. Agronomy Journal 100:971-976. doi:10.2135/ cropsci2008.01.0009.

Lima, S.F., R.C.F. Alvarez, G.F. Theodoro, M. Bavaresco, e S.K. Silva. 2012. Efeito da semeadura em linhas cruzadas sobre a produtividade de grãos e a severidade da ferrugem asiática da soja. Bioscience Journal 28:954-962.

NIMH. 2015. ImageJ. National Institute of Mental Health (NIMH), Rockville, Maryland, USA. Available at http://rsb.info.nih. gov/ij/index.html (Accessed March 2015).

Procópio, S.O., A.A. Balbinot Junior, H. Debiasi, J.C. Franchini, e F. Panison. 2013. Plantio cruzado na cultura da soja utilizando uma cultivar de hábito de crescimento indeterminado. Revista de Ciências Agrárias 56:319-325. doi:10.4322/rca.2013.048.

Robinson, S.L., and J.R. Wilcox. 1998. Comparison of determinate and indeterminate soybean near-isolines and their response to row spacing and planting date. Crop Science 38:1554-1557. doi:10.2135/cropsci1998.0011183X003800060024x.

Soares, I.O.,P.M. Rezende,A.T. Bruzi, A.M. Zuffo, E.V.Zambiazzi, V. Fronza, et al. 2015. Interaction between soybean cultivars and seed density. American Journal of Plant Sciences 6:14251434. http://dx.doi.org/10.4236/ajps.2015.69142. 
Specht, J.E., D.J. Hume, and S.V. Kumudini. 1999. Soybean yield potential-A genetic and physiological perspective. Crop Science 39:1560-1570. doi:10.2135/cropsci1999.3961560x.

Suhre, J.J., N.H. Weidenbenner, S.C. Rowntree, E.W. Wilson, S.L. Naeve, S.P. Conley, et al. 2014. Soybean yield partitioning changes revealed by genetic gain and seeding rate interactions. Agronomy Journal 106:1631-1642. doi:10.2134/ agronj14.0003.
Tian, Z., X. Wang, R. Lee, Y. Li, J.E. Specht, R.L. Nelson, et al. 2010. Artificial selection for determinate growth habit in soybean. Proceedings of the National Academy of Sciences of the United States of America 107:8563-8568. doi:10.1073/ pnas.1000088107.

Walker, E.R., A. Mengistu, N. Bellaloui, C.H. Koger, R.K. Roberts, and J.A. Larson. 2010. Plant population and row-spacing effects on maturity group III soybean. Agronomy Journal 102:821-826. doi:10.2134/agronj2009.0219. 